\title{
19. Tales of Mystery and Imagination from the Tweed River: Shaping Historical-Consciousness
}

\author{
Philip Morrissey
}

The invitation to submit an essay as part of this collection on ego-histoire has enabled me to reflect on a series of intra-Aboriginal narratives between different peoples along the Tweed River that I had been exposed to in my early childhood. Over the passage of time, I have begun to understand how these narratives (and vivid fragments of story) have formed my basic dispositions, in a manner analogous to the Bourdieuan concept of habitus. Bourdieu sees habitus as 'a system of lasting, transposable dispositions which, integrating past experiences, functions at every moment as a matrix of perceptions, appreciations, and actions' (Bourdieu 1990, pp. 82-83). The dialogic, quasi-magical world represented in these stories has intrinsically shaped my historical-consciousness and underscored my subsequent work in the academe, both in bringing Aboriginal epistemologies to the fore of pedagogy in Aboriginal studies at the University of Melbourne, for example, and in exploring notions of the uncanny in Aesopic philosophy (Morrissey 2011).

In what follows I quote Martin Buber from his preface to Tales of the Hasidim: The Early Masters about the significance of the 'naked story' as a framework for reflection (Buber 1968, p. ix). For, like Buber's Hasidic tales, what I relate here are not 'prosaic facts' but 'illuminative tales' suggesting hidden realities and addressing fundamental structures of human life. For Buber, the form of the naked story is an epistemology in itself. This is resonant, too, with Aboriginal practices of story-telling, including in relating historical stories. In offering these stories as a form of ego-histoire I deploy Buber's edict of presenting the unadorned story as a theoretical frame, inviting the reflexivity of the reader.

A personal legacy of the stories I include below, such as in 'Dancing Curlews,' is an enduring and profound belief in the extra-dimensional qualities of existence and the uncanny integrity of animal life. These themes also thread though my research and my teaching. Other stories below, such as 'The Fight' - the title is a reference to the famous William Hazlitt essay of 1822 (Hazlitt 2000)-imprinted me with an intuition of the connection of sex with violence, and love with death. This may have run counter to the banal platitudes of political correctness but it did provide a pathway to understanding great art and literature, so that when I read, as I relate at the end of the essay, Richard Hughes' A High Wind in 
Jamaica, in the Tweed River, its dark themes, enunciated within the immediate and disquieting world of post-slavery, were a continuation of what I had already began to understand through story. Finally, the story 'Uncle Tommy Norley' and its tale of intra-Aboriginal violence introduced me to an early form of selfreflexivity and individualism. It was clear to me even then that there were no unified narratives of communal resistance to colonisation. Rather, the colonial world I experienced through the stories of my family was one of individuals working, fighting and dying. And it is this that influences what I teach and what I write.

This collection of stories is one I've written down for the first time. They are stories that were told to me by my mother, my grandmother or my uncles, or stories that were told by them in my presence. The exception is "The Dave Sands Story', which was told in a communal setting by a senior Aboriginal woman from Kempsey, New South Wales. In retelling that story I've attempted an atmospheric, interpretive mode of writing. I've related all the other stories in plain English because with the passage of time I'm unable to do justice to contexts in which I heard them and the specific vernacular used by the storytellers. The stories which feature my mother and uncles as children take place in the 1930s. 'The Fight' is set in the late-1930s. The incidents described in 'Uncle Tommy Norley' took place in the late-nineteenth century. In each instance, I believe that I was the sole living repository of the story at the time of writing it down.

What has been amusing for me is the consideration that, while my professional life as an Aboriginal scholar in the academe has not depended on me presenting myself as an elder or custodian of an oral tradition, I somehow metamorphose into that stereotypical role when writing down these stories. In contradiction to this stereotype, I feel strongly that the stories I recount below have individualised me rather than contributed to the production of a generic Aboriginal subject. In this regard I am ambivalent with respect to Deleuze's and Guattari's thesis on a 'minor literature' as 'deterritorializing one terrain as it maps another', in its presupposition of a collective enunciation (Deleuze \& Guattari 1986, p. 18).

The radical content of the 'Uncle Tommy Norley' story, for example, disrupts other Indigenous and non-Indigenous histories of the frontier, some of which have become almost normative in the way they represent the coloniser/ Aboriginal binary. The 'Uncle Tommy Norley' story challenges us more broadly to think of the extreme violence of the Queensland frontier and how that could also translate into intra-Aboriginal violence; of the emerging affiliative relationships between coloniser and Aboriginal, often based on work; and the conflict between tradition and modernity within the Aboriginal world itself. 
My experience of the storytellers and stories coincides with that of the Italian playwright and Nobel Laureate, Dario Fo, when he writes of the fabulatori, the storytellers of his childhood who, 'with their language and tales made an indelible mark on my future choices and on my way of judging events and characters in both fantasy and reality' (Fo 2005, p. 62). The fantastic, or the uncanny, became for me part of the fabric of an everyday reality that could never be simply prosaic, shaping the current of my subsequent work.

The Tweed River, where many of the stories are set, is a tidal river on the New South Wales/Queensland coastal border. The stories set along the river all take place in a time when there was a hybridised community of Aboriginal and South Sea Islanders living there. The generic term Dugai was used to refer to white people; the community of Aborigines and South Sea Islanders referred to themselves as Goories. Where appropriate, I have deployed these terms in my essay. It would be a mistake to attempt to frame these stories with a contemporary discourse of 'traditional owners' and 'country', for these concepts were not in use at that time and 'skin colour' was the critical point of difference between Dugais and Goories.

Paddy Roe's Gularabulu: Stories from the West Kimberley, edited by Stephen Muecke, provides a further useful frame of reference for thinking about the stories I've made public here. In his introduction, Stephen Muecke classifies Paddy Roe's stories as trustori (true stories), bugaregara (stories from the Dreaming), and devil stori (stories about devils and spirit-beings) (Roe 1983, pp. vii-viii). The stories that played a role in forming my worldview fall mainly into the categories of trustori and devil stori. The Dreaming was never an overt factor in understanding the river or the country that surrounded me. The strange and miraculous found in some of the stories was logically related to the superabundance of nature itself. If the river was full of sharks and overflowing with fish, oysters, and crabs, why would its riparian surrounds not include spirits and other strange beings?

\section{Devil Storis}

The following devil storis are set on Greenbank Island. Greenbank Island was once an island on the Tweed River, but is now joined to the shore and has transformed into a banal suburb of Tweed Heads. Greenbank Island was home to a succession of Aboriginal families in the early-twentieth century. People lived in houses, widely spaced over the island, and there were never more than a few families living there at any one time. The last Aboriginal family lived on the island in the 1960s, and for this particular family, as for my family, the island seems to have functioned as a transitory space when first moving to 
the Tweed River from Queensland. It is quite possible that those families who lived there in the early part of the twentieth century were seeking lives with maximum freedom from state control. In the 1930s the Tweed River was still full of freshwater sharks and the island was resonant with the uncanny 'energies' of an earlier time. The only way to get to the island was by rowing a boat. My mother told of rowing across the river with warm bread purchased from the bakery and, on one occasion, of the bread falling into the water on the floor of the dinghy. When my family left the island sometime after World War Two, a young fisherman named Matt Philp rowed the family's furniture in a dinghy up the Tweed River to their new home. Here are the devil storis from that period.

\section{Tiger and Patchy}

At certain times all the adult males in the family would have travelled away from the Tweed River seeking work. My grandmother and younger family members would be at home alone. Indoors, in the evenings, they would hear the family dogs outside barking, growling, and yelping, and then some spirit or being would throw the dogs - and sometimes the family goats - onto the roof. Occasionally, my mother and uncles would see the dogs, Tiger and Patchy, growling and flinching away from these invisible or imaginary creatures.

\section{The Size of a Calf}

My Uncle Darcy was walking though the bush once with another boy when they encountered a four-legged animal the size of a calf. The creature entered the river and began to swim, but instead of dog-paddling it swung its forelegs in the manner of a freestyle-swimming human.

\section{Shaking Bushes}

One day, as dusk was setting in, my mother was with Uncle Darcy on the river hunting for sand crabs. The technique involves pinning the crab to the sandy river-floor with a thin pole and then picking it up by its rear legs before it can escape. My mother was after one especially large crab while Darcy, who was becoming impatient, waited. Finally she gave up and ran to join him. As she ran, the bushes on the side of the bush track began to shake and quiver, without any sign of wind or other intervention.

\section{Dancing Curlews}

Curlews figure in stories from many Aboriginal communities across Australia, often as portentous omens. My mother told stories of curlews seen dancing 
around camp fires, and of being confronted on lonely bush tracks by dancing curlews with coal-red eyes. Here the suggestion is that curlew is almost like a medium - open to possession by a spirit. It is intriguing as to why such an inoffensive bird has acquired such a reputation.

\section{The Chain Man}

The Chain Man was a dreadful being that walked the mangrove islands and estuaries of the Tweed River carrying a clanking chain. There was never any report of the Chain Man actually harming anyone but, like the fabled Medusa, he was so terrible in aspect that anyone encountering him was liable to die of fright. When I was in a relatively isolated part of the river with other boys, we would mock-frighten each other with stories of the Chain Man. The one person who I had heard of as actually encountering The Chain Man was an old non-Indigenous fisherman, named Mr Alvin. After the encounter he returned to Greenbank Island in a state of shock, and was nursed for several days until his recovery by my grandmother. This was told to me by my mother. The Chain Man was an actual being who lived on the river, not a spirit. Mr Alvin believed that he had seen the Chain Man, but might the original story have been based on nineteenth century encounters with an escaped convict from the nearby Moreton Bay Penal Settlement? Chains and leg irons were worn by convicts.

\section{Trustoris}

\section{The Fight}

Bare-knuckle fights bore no relationship to brawls or street fights and were fought under classic London 'Prize Ring' rules, with fights ending when a combatant was unable to rise from a knockdown, or in the Aboriginal way, with real-time arbitration. Spectators might intervene when they thought points of honour and precedence had been adequately satisfied. Fights were usually scheduled for a Sunday morning when people had free time. Many of the challenges, I assume, were issued on the Saturday night when people were socialising and drinking. In a spirit of sportive violence, Eddie Cavanagh, the key figure in 'The Fight', as the Sunday events were known, would challenge the crewmembers of the coastal steamers docking into Tweed Heads in the early part of the twentieth century. As a small boy I witnessed a fight in the classic bare-knuckle style. No punches were thrown but I was impressed by the fierce menace of hissing breath, rolling fists, circling, and flatfooted shuffling of the fighters. My grandmother related the story of how her oldest and favourite son, Eddie, arranged to fight a rival who was attended by his extended family, 
while she was the only person who turned up to support Eddie. My mother, less into the romance, provided the background: the fight was over an enchanting woman, though it was more about honour than anything else. Eddie had refused to marry the woman in question and she had commenced a parallel relationship with another man. Whether the combatants consciously realised it or not, the fight was about orderly transition in personal relationships. A comparative understanding from the Kimberley region of Aboriginal Australia is seen in the late Paddy Roe's narrative, 'We better go back to country' (Roe 1984, pp. 106-112). After running away with another man's woman, Paddy returns to face punishment from her former partner. The punishment is administered publicly and the matter resolved.

Uncle Darcy was also a noted bare knuckle fighter and, as it was related, would not tell anyone if he had a fight arranged but would simply get up at dawn and head off. The better the fighters, the more serious the fights. Once, a noted bareknuckle fighter, a white ${ }^{1}$ challenger from somewhere else, turned up drunk one evening, issuing Darcy a challenge that was accepted for the following morning. Both fighters damaged each other and 'Sonno' (Darcy's nickname) was spitting blood for days after the fight. This was an agrarian world, in many respects closer to the Wessex of Thomas Hardy's novels than the world of the Protectors of Aborigines, which left me with an acute awareness of the body as the locus of individuality, sex, love and violence. In this world this violence could sometimes extend to crimes of passion, ending in death.

\section{Professional Boxing: The Dave Sands Story}

This is the one story in this collection that was told by a non-family member. The storyteller was an old woman, the grandmother of the last Aboriginal family to live on Greenbank Island, and it was told with a deliberate point to be made. In content the story was simple: Dave Sands (1926-1952), an internationally renowned Koori boxer during the early 1950s, unable to get a world title fight, went timber-cutting with his brothers and was killed when the truck he was driving ran off the road. His untimely death, as the manner in which the story was told made clear, was causally related to the injustices the Aboriginal fighter suffered throughout the latter portion of his boxing career, as well as more generally to his destiny as an Indigenous Australian. As an appendix to the story, the old woman also spoke of Ron Richards (1910-1957), a great Aboriginal fighter of the 1930s and 1940s, who was a precursor to Dave Sands as Aboriginal Australia's first national hero. She narrated her encounter with Richards as an old man, telling of finding 'this old fulla' on the street and taking him home for a meal. After eating in silence, the old man identifies himself:

1 I I use the term 'white' here because it was an important element in the original telling of this story. 
'I'm Ron Richards.' The Richards story, however, did not have the impact of the Dave Sands story: it was too easy to visualise. I could picture the old man eating quietly, possibly lost in his own thoughts, and then, as a gesture of thanks for the meal, revealing his identity: 'I'm Ron Richards.' That story's message was simpler: decline after success, weakness after strength. Richards' destiny was a common one for Aboriginal men: a good man destroyed by alcohol. Therefore the evident point of the story was simpler. But the Sands story was mysterious, pointing at something beyond its immediate content. Sands had achieved, at the time of his death, an unheard-of level of success and acceptance in the nonAboriginal community. The force of the story came from its warning that success was a property of settler society and, like fire, unstable and dangerous in its effects. But along with caution, the story spoke of desire; Sands' inspirational achievements, accomplished in daring relation to settler society, are remembered and presented by the storyteller a decade after his death as a programme of self fulfilment as well as risk. In its compression of themes of success, mortality, and agency, the story served as a parable addressing the policy of assimilation and the inevitably increased level of interaction between settler and Aboriginal Australians.

\section{Uncle Tommy Norley}

This is the only story I know of that deals with intra-Aboriginal violence on the frontier. The story is incredibly dense, and is deserving of extended analysis from the listener. In writing it down I've tried to keep in mind the following from Martin Buber: 'the anecdote, as well as the short story, is a species of condensed narrative concentrated in one clearly outlined form. Psychology and adornment must be eschewed. The more "naked" it is, the more adequately it fulfils its function' (Buber 1968, p. ix). The story was told to me by my mother.

Uncle Tommy Norley was travelling with his (white) boss in North Queensland. They camped outside a town, and Tommy's boss went into town to buy food. While the boss was away, an Aboriginal warrior came out of the bush with a tomahawk and attacked Tommy. Tommy took the axe off him and killed him.

When the boss returned and learned what had happened he said to Tommy, 'Don't tell anyone about this or we'll get into trouble'. They took the body and tied it to the roots of a mangrove tree, underwater. That night a big wind came up. The dead man's spirit emerged from the water and tried to roll Tommy and his boss into the campfire. 


\section{The View from Terranora}

Terranora is now listed as a suburb of Tweed Heads but at one stage was made up of small crop-farms growing beans, peas, or tomatoes. The relation between Goories and Dugais was negotiated around work, and the Goories had a sense of their own dignity, which masked the reality of the rapacious and disrespectful behaviour of white men in relation to Aboriginal women. In the early 1960s, when most Aboriginal people on the Tweed did not own cars, small crop-farmers would collect Aboriginal workers from their homes for bean and pea picking, usually in open trucks. This work was mainly done by women, although older men and men between jobs would also pick beans. I once heard one school teacher talking to another about the 'colourful clothing' of the women bean pickers: a local version of the Ceylon tea pickers. When I told my mother she simply laughed.

Taking the day off from school I would wait with anticipation to see who else was also not going to school that day. Each of the working parties had a 'ganger' who organised the work gangs and negotiated with the farmer. The names of farmers I recall include Burger, Strong, and Abernathy. The gang I remember most strongly was led by a senior woman, named Ruby Roberts, and I looked forward to the smokos and lunch break when I would have the opportunity to listen to older people such as Ruby talk. My usual mode of work was to pick beans until the sun had fully risen and it had become warm, and then start playing, returning for bursts of work. The supreme pleasure of the bean picking excursion, however, was the early morning drive up in to the hills from where I could look down on the mist rising off the Terranora Lakes. As well as the aesthetic dimension of such a sight, it gave me a sense of the more remote parts of the river where the Chain Man might still be encountered.

\section{Finally}

One day in summer, roaming around the river I found two books that had been washed up by a high tide. I took them home and put them on top of a shed to dry in the sun. When I eventually remembered the books and went back to get them I found that they had dried in a readable state. One was an orange-covered Penguin paperback, John Buchan's Greenmantle, the other a hardback edition of Richard Hughes' A High Wind in Jamaica. I read Greenmantle easily, enjoyed and then forgot it. Richard Hughes was more problematic for a pre-adolescent. I still retain the details, as well as the major themes, including the relationships of the older girls with the captain and the mate, and the eventual perfidiousness of the children, against the backdrop of the immediate post-slavery world. 
Perhaps the quasi-miraculous aspect of this - the two books dropped into the river somewhere, or possibly, even into the ocean, being carried together and then washed up by the tide - was a harbinger of what was to come.

\section{References}

Bourdieu, P 1990, The Logic of Practice, Polity Press, London.

Buber, M 1968, Tales of the Hasidim: The early masters, Schocken Books, New York.

Buchan, J 1916, Greenmantle, Hodder \& Stoughton, London.

Deleuze G \& F Guattari 1986, Kafka: Toward a minor literature, University of Minnesota Press, Minneapolis.

Fo, D 2005, My First Seven Years (Plus a Few More), Methuen, London.

Hazlitt, W 2000, The Fight and Other Writings, Penguin, London.

Hughes, R 1929, A High Wind in Jamacia, Chatto \& Windus, London.

Morissey, P 2011, “Old Cobraboor': Colonial violence and Aboriginal modesty', in P Morrissey (ed), Aesopic Voices: Re-framing truth through concealed ways of presentation in the 20th and 21 st centuries, Cambridge Scholarly Publishing, Cambridge, pp. 358-368.

Roe, P 1984 'We Better Go Back to Country', in K Benterrak, S Muecke \& $\mathrm{P}$ Roe, Reading the Country: Introduction to nomadology, Fremantle Arts Centre Press, Fremantle, pp. 106-124.

Roe, P 1983, Gularabulu: Stories from the West Kimberley, (edited and with an introduction by S Muecke), Fremantle Arts Centre Press, Fremantle. 
This text taken from Ngapartji Ngpartji: In turn in turn:

Ego-histoire, Europe and Indigenous Australia

Edited by Vanessa Castejon, Anna Cole, Oliver Haag and Karen Hughes,

published 2014 by ANU Press, The Australian National University, Canberra, Australia. 